\title{
Why is the Turin Shroud Not Fake?
}

\section{Giulio Fanti*}

Department of Industrial Engineering, University of Padua, Italy

Submission: November 23, 2018; Published: December 04, 2018

*Corresponding author: Giulio Fanti, Department of Industrial Engineering, University of Padua, Via Venezia 1 - 35131Padova, Italy

\begin{abstract}
Summary
The Turin Shroud [1-11], the Holy Shroud or simply the Shroud (Figure 1) is the archaeological object, as well as religious, more studied in the world. From a scientific point of view, it is important because it shows a double image of a man up to now not reproducible nor explainable; it is also religiously important because, according to the Christian tradition, it shows some traces of the Resurrection of Jesus Christ. A recent paper [12] showed why and in which sense the Shroud is authentic, but many persons still keep on stating the contrary, probably pushed by their religion beliefs that arouses many logical-deductive problems. Consequently, some researchers influence the scientific aspects of the most important Relic of Christianity based on their personal religious aspects thus publishing goal-oriented documents.
\end{abstract}

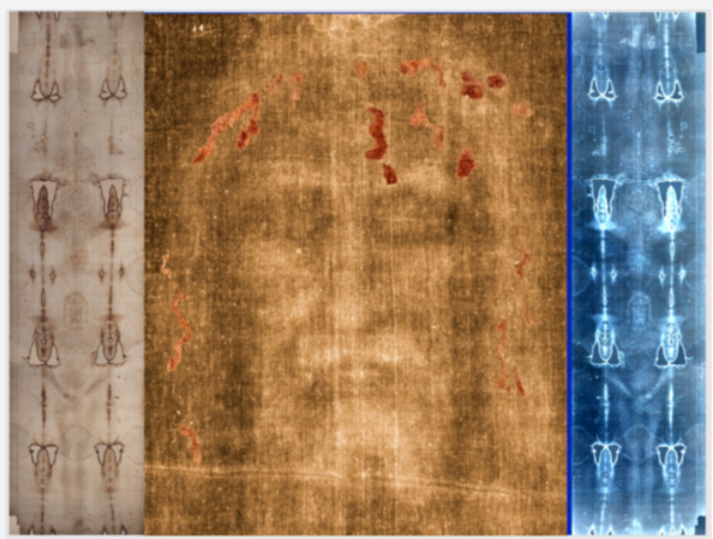

Figure 1: The Turin Shroud (left) and its negative image (right) with zoom of the face in negative (center) with the bloodstains in positive.

This work considers some debatable facts frequently offered during the discussions about the Shroud authenticity, by commenting a recent paper [13]. Many claims, apparently contrary to the Shroud authenticity, appear blind to scientific evidence and therefore require clarifications. The assertions under discussion are reported here in bold for clearness.

\section{What is the Shroud?}

The Shroud is the only Relic that boasts not only dozens of publications in specialized scientific journals [14-22], but also hundreds of books in dozens of different languages; you cannot count the articles and notes that come out almost daily in the newspapers and on the web. It is an ancient linen cloth, $4.4 \mathrm{~m}$ long and $1.1 \mathrm{~m}$ wide, which enveloped the corpse of a tortured man, scourged, crowned with thorns, crucified and pierced by a spear in the chest. Many are convinced that the Shroud is the sepulchral cloth of Jesus Christ resurrected there after thirty-forty hours from the wrapping.

The double body image there impressed has been the subject of intense studies especially during the twentieth century, but even today, it is not technically reproducible and cannot even be explained in a scientific way [19-21].

On the Shroud, various signs are visible [25], not easily comprehensibleatfirstglance:thedoublemirrorimage,frontalanddorsal, of a man, the bloodstains corresponding to his wounds when he was wrapped, the stains caused by water, the traces and the holes caused by the fire of Chambéry of 1532 and other minor signs. Its body image is still unexplainable today, but some hypotheses of image formation, also connected with experimental test, try to suggest an explanation. Among the many hypotheses [20,38] that of a burst of energy coming from the inner of the human body, perhaps also of electric type [23], appears one of the most reliable up to now.

By authenticity [12], and therefore not a fake, we mean here a burial sheet, of very ancient manufacture, about 2000 years ago, which wrapped the corpse of a severely scourged man, crowned with thorns, crucified and dead, who could be identified with Jesus Christ. In this case, the conditional is necessary because it is not currently possible to identify with full scientific certainty the name of the person who was wrapped in the Shroud, even if the 
correlation between what is detected experimentally on the Relic and what we read in the Gospels helps a lot to recognize this Man.

The origin of this linen Sheet is still unclear today, but according to a recent DNA analysis from the dust aspirated by the Relic [14], it appears to be of Indian origin and probably brought in Jerusalem the first century AD. Many historians [2,10,11], by identifying the Shroud with the Mandylion, see the Relic in Edessa, the current Salinurfa in Turkey in the early centuries until it reached Constantinople until its fall in 1204. The Shroud appeared in Lirey in 1353, and it was subsequently kept in Chambery from 1502. In 1578, it was brought to Turin where it remains until today.

In 1988 the Shroud was radiocarbon dated by three famous laboratories [17] and it turned out to be an age of 1325 AD with uncertainty of \pm 65 years, but this result was widely criticized $[24,26,31]$ both for procedural and statistical problems. Five different methods, independent of each other, instead agree with the assignment of the first century AD the probable age when the artifact was built $[12,24,26]$. Samples of blood crust have been analyzed and the blood resulted considerably deteriorated, very brittle and mixed with pigments due to a restoration [27]. Recently, the presence of biliverdin [28], caused by the degradation of hemoglobin in the blood of the Shroud, typical of a traumatized person has been detected.

\section{Assertions on the Shroud history}

\section{The known Jewish shrouds of the first century AD are} completely different from the Shroud

Indeed, the textile characteristics of the Shroud do not seem to be attributable to the Palestinian area, and a recent study on the DNA [14] of powders aspirated by the Relic proposes an Indian origin.

\section{The fabric texture have a simple 1:1 structure while the} Shroud is herringbone 3: 1

The anticlockwise " $\mathrm{z}$ " twisting is typical of fabrics made for high-ranking priests (Book of the Exodus of the Bible) and the Shroud is just a hand-woven sheet with some defect of weaving, but of high quality with a particular structure 3: 1 and consistent with the fact that it may have been purchased by a wealthy person like Giuseppe d'Arimatea. Trade between India and Palestine was flourishing two millennia ago and it is therefore possible that the Relic was bought in India and brought to Jerusalem

\section{The Twisting of the threads is clockwise while the Shroud is anti-clockwise}

The Shroud could be not of Palestinian origin as other shrouds found there. In addition, the Jewish Shrouds discovered around Jerusalem are different because they wound corpses for more than thirty-forty hours as the Shroud did; in fact, it is scientifically demonstrated that the body disappeared from the Sheet after this relatively short period in a way not yet explained. This is shown for example by the blood redissolved by fibrinolysis [4] in the humid environment of the sepulcher. In fact, if the corpse, which does not show any sign of rotting, was extracted or stolen by someone, it would have caused some smudges on the decals of the wounds, which are instead absent on the Sheet.

The Shroud cannot be the unique funerary sheet because other clothes were used together with the shrouds at that time

Many scholars believe that rolls of bandages impregnated with anti-putrefaction substances were placed at the side of the Shroud [9], but obviously, there are no photographs of its arrangement in the sepulcher.

The historical age of the Shroud is $\mathbf{1 3 5 5}$ when it appeared in France, in Lirey. There are no documented traces of the Turin Shroud before this period. A memorial of the bishop Pierre d'Arcis (1389) reports the furious polemics immediately following the first exposition and his declaration of a fake

Without going into detailed historical discussions, various authors $[2,10,11]$ have highlighted several traces of the presence of the Shroud from the first centuries after Christ and have reported the controversy with P. d'Arcy. They evidence that the bishop, envious for the great number of persons that visited the exhibition, thus deserting his church, declared that the Shroud was a painted relic. Today we know that the Relic is certainly not a paint. It is curious to add that some these documents about the Shroud were even officially corrected a posteriori. Instead, we must observe that a numismatic study on the Byzantine coins minted starting from $692 \mathrm{AD}$ [4] shows, with a probability very close to $100 \%$ that the Shroud was taken as a model for the representation of Christ. The presence of the Shroud of Jesus in the first centuries AD it is not only confirmed by numismatic analysis, but also by numerous examples of Byzantine iconography.

For several centuries, the Church itself considered the Shroud to be a forgery, while allowing its growing cult

The statement seem to be lacking of some information. In fact, already when the Relic was at Chambéry in France, Pope Julius II in 1506 approved the cult and the Mass of the Shroud, fixing the it on May 4 and declaring that not only the Shroud had to be venerated but also worshiped because it contains a part of the body of Jesus Christ: the blood [30]. Many popes in the past centuries were in great favor of the authenticity of the Shroud and even in these decades, all the popes venerated the holy Sheet also declaring it a Relic.

Shroud dating with the Carbon 14 method. In 1988 small samples were sent to the three laboratories that established an age for the Shroud between 1260 and 1390 in agreement with the historical age (see Point 3.5)

The 1988 Carbon 14 dating of the Shroud has been the subject of extensive discussions, above all because the measurement was affected by various procedural and statistical problems $[2,25,26,31]$. Five different methods, independent of each other, 


\section{Global Journal of Archaeology \& Anthropology}

instead agree with the assignment of the Shroud age to the first century AD as probable period when the artifact was built. A Project of the University of Padua has allowed the development of alternative methods of chemical and mechanical dating. Chemical methods based on FT-IR / ATR and Raman spectroscopy dated the Shroud to $300 \mathrm{BC} \pm 400$ years and 200 B.C. \pm 500 respectively with a $95 \%$ confidence level $[3,25,26]$.

The mechanical method based on the analysis of some parameters such as the breaking strength, the Young's modulus and the loss factor, after an adequate calibration based on the results of two dozen samples of known age, indicated an age of the Shroud of $400 \mathrm{AD} \pm 400$ with a $95 \%$ confidence level. To these three methods, a numismatic one that sees the Shroud before the seventh century AD [25], see Figure 2, and another chemical method developed by the American chemist Raymond Rogers, based on estimates of the kinetic constants for the loss of vanillin from lignin, which sees the ancient Shroud from 1300 to 3000 years must be added [7]. The following questions therefore come out: why the person who writes against the Shroud authenticity forgot all these scientific results? Is it correct from a scientific point of view to select only the results in favor of a particular thesis?

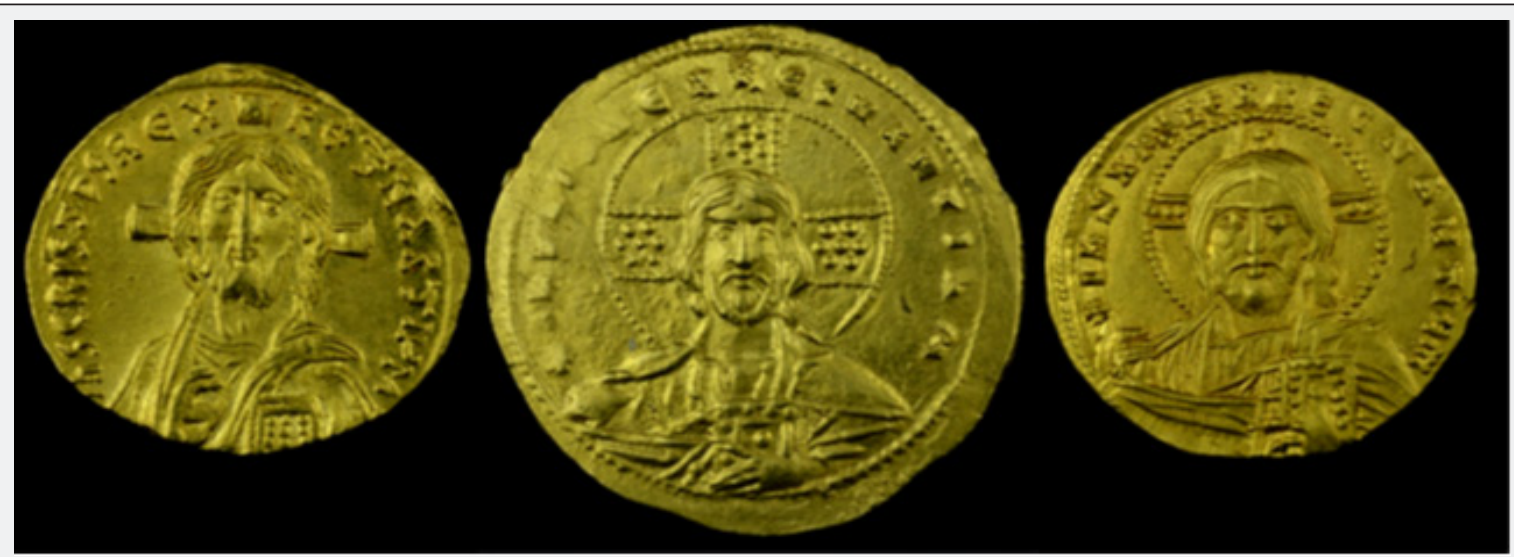

Figure 2: Three golden coins minted during the Byzantine Empire starting from 692 AD (by emperors Justinian II, Basilius II and Constantine VII, respectively from the left to the right) showing faces of Jesus Christ very similar to the Shroud face.

\section{Assertions on the Shroud image}

The properties of the Shroud image are various and very peculiar, and unreproducible all together

Among them, we find the following: photographic negative, 3D, slight burning, fluorescence; the image resides in the most superficial fibers of the threads; it is due not to the presence of pigments, but to a coloring produced by oxidation and dehydration of the flax fibers. Some experiments have been done and for example, the paper [32] well reproduced the characteristics mentioned above. It is logical that, however accurate reproductions require aging not artificial but of centuries. Probably only an imitation of the salient characteristics is expected, and not the microscopic properties of the image. The meaning of experiments is to suggest a plausible and simple mechanism, which realizes the formation of the image and its characteristics, rather than obtaining a perfect but impossible reproduction.

This analysis of the body image of the Shroud here reported is rather brief because the particular characteristics, unreproducible all together, are many others too. For example, we also read in the paper what follows. A body image is visible in areas where bodycloth contact was certainly absent, like the space between cheeks and nose; the image resolution is $4.9 \pm 0.5 \mathrm{~mm}$ but no contour is well defined; the Shroud wrapped the body a human corpse; the distortions of the image of hands, calves and torso correspond to those obtained by a man wrapped in a sheet; the pronounced rigor mortis of the body is evident; the image shows no signs of putrefaction.

The colored linen fibers are situated only on the outermost parts of the threads, leaving the inner fibers uncolored, but the coloring does not appear under the threads that cross each other in the weave of the fabric. The image fibers are adjacent to noncolored fibers and the color is concentrated at the crevices where two or more threads cross. The color resides on the outer layer of the linen fiber, often 0.2 micrometers thick (interpreted as the primary cell wall of the fibers) so the cellulose of the main part of the fibers (having diameters of 10-20 micrometers) is not colored. The fibers are uniformly colored around their cylindrical surface, while variations in color intensity can be detected along the fiber axis. The author [32] forgets the published criticism [33], and his comment requested by the editor to this review was never sent. This criticism highlights a series of differences detected in the result of the experiment; in synthesis, the reproduced body image was comparable only at macroscopic level, but not at a microscopic level.

The image of the Shroud lacks the geometrical deformations to be expected from an interaction between cloth and body. While testing it experimentally, it results a lateral distortion typical of the "Agamemnon mask" very different from the Shroud face

This is a too hasty conclusion. Other experimental tests [19] performed at Padua University instead show just the opposite. 
The problem resides in the fact that often too simplistic tests are performed and they do not consider the actual wrapping of the Shroud around a body placed in a position not perfectly supine for the cadaveric rigidity assumed on the cross and with the mouth wrapped by a chin-band. Instead, pseudo-cylindrical distortions are easily visible on the body image, especially at the thorax and calves area.

Many sub-micron red ocher particles have been found, in the image area and, more numerous in bloodstains

This statement refers to a dated study performed by W. McCrone [34], but immediately contradicted by the STURP $[1,8,35]$ scholars who, starting from 1978, carried out the most detailed scientific analyses on the Shroud. The author of this paper has analyzed dozens of fibers from the image area too and confirms that the coloration of the flax fibers is not due to the so-called particles of "sub-micron size", but rather to a chemical reaction of the surface layer of the flax fibers $[19,20]$.

According to STURP, the yellowing of the image fibers could also have a chemical cause

Actually only two scientists of the STURP, L. Schwalbe and R. Rogers, made a statement like this, but others like John Jackson $[6,35]$ concluded that the body image was due to a burst of energy, very brief but very intense.

\section{If it is a fake, how was the body image done?}

An incomplete list of scholars who have proposed some techniques to reproduce only some of the many features of the Shroud image is reported in the work under discussion; a broad critique of these hypotheses is instead reported in the papers $[6,20]$ with many hypotheses of body image formation.

The hair, among other things, in a prone body would fall on the sides of the face and could not leave the kind of visible mark on the Shroud

First, it does not appear that the Man of the Shroud had been laid prone, but supine with his cadaveric rigidity assumed on the cross $[15,16]$. Furthermore, it is necessary to take into account the probable presence of a chin and the fact that probably sweat, blood and possibly ointments impregnated the hair; their presence could have produced the particular image we observe on the Relic. In addition to this, we should remember that the electric effect supposed for the body image formation [23] could have contributed to the production of this image of "soft hair".

\section{Assertions on the Shroud Blood}

The blood on the Shroud is too red to be credible. It is instead well known that the blood, oozing from a living body, soon becomes very dark due to the degradation of hemoglobin

Those who make sentences like this are not sufficiently update. In fact, a recent paper has been published [27] based on spectrometric analysis, showing that the blood traces are of real blood, but altered by the high temperatures of the sixteenth century fire of Chambéry [35-38]. These blood traces, weaken over the centuries, were probably revived a few centuries ago by adding pigments of red ochre and cinnabar, but no binder so as not to disfigure the Relic too much. The addition of these red pigments can explain why the bloodstains on the Shroud are so red.

It is impossible for the blood to escape from the scalp on the outer surface of the hair, without spreading it everywhere

Before declaring an impossibility in a rough manner, it would be necessary to carry out experimental tests, bearing in mind that the blood crusts formed in the hair produced by the crowning of thorns, were re-dissolved by fibrinolysis $[18,25]$ in the humid environment of the sepulcher.

A recent experimental study [39], conducted according to the technique of Bloodstains Pattern Analysis showed the improbability of the position of various traces of blood of the Shroud

Many scientist marking the work as a non-convincing study has criticized the study in question. Among the other critics, the paper does not sufficiently documents the tests performed, does not sufficiently face the Shroud problem, it is limited and the conclusion is supported by too simplistic experiments. Therefore, the results reported in that paper are obviously not significant. Parallel experiments also performed by a scientific group including the author of this paper instead show the full compatibility of the Shroud bloodstains with the traces of blood produced by a tortured man.

A commission formed by Cardinal Pellegrino in 1973 did not detect blood, but the presence of insoluble reddish granules. In 1980 Walter McCrone [34] found traces of pigments such as red ocher and cinnabar but found no blood. Some of McCrone's conclusions have recently been confirmed in $\mathbf{2 0 0 8}$ by Raman spectrometry [22]

This is a typical example in which very recent important results are forgotten [27], while others that are dated are preferred and mentioned alone because in favor of the supported thesis. In a recent work [27] it is shown, through Raman and FTIR spectrometric analyses, that the traces blood cells are real blood. It is strange that who cites the work of 2008 [22] forgets to note that among the "other pictorial pigments" was also found the lapis-lazuli, which is a blue pigment certainly not used for the body image of the Shroud. Instead, this pigment leads to think to the presence of external contaminations, perhaps due to adherence with other painted shrouds that became therefore relics by contact,

Can Scientists in Favor of the Shroud Authenticity Meet Together with Those Against the Authenticity in Order to Find a Common Agreement?

The answer would be certainly addressed to a clear yes, but can be thorny because there is frequently no clarity in the open comparisons between scientists pro and against the Shroud authenticity. 
a. As reported above, some important arguments in favor of authenticity are forgotten in an apparently voluntary way. For example the scientific fact $[6,19,20,25]$ that the Shroud wrapped the corpse of a severely tortured man, scourged, crowned with thorns and crucified according to Roman techniques is forgotten when a painting technique to explain the body image of the Shroud is supposed. Other recent results are also forgotten, such as the numismatic dating of the Shroud through the Byzantine coins [25], which sees it already in $692 \mathrm{AD}$, while someone keeps on stating that the Shroud did not exist before 1300 AD.

b. The reality of scientific experiments are distorted and the global result is forgotten at the expense of a particular detail useful for the present goal. For example the work [22] detected the presence of pigments of various colors on the Shroud, probably due to the contamination with other paintings, but only the red pigments have been mentioned in a paper [13] to sustain a particular thesis.

c. Statements relative to a distorted reality can be found when for example we read that pollen grains detected by a researcher on the Shroud have not been seen afterwards [13]. In fact, the same kind of pollen grains [29] together with other particles coming from powders vacuumed from the Shroud have been recently detected thus confirming more dated results.

d. Not correct statements are still frequent like that asserting that the sample of Shroud used in 1988 for radiocarbon dating had been perfectly cleaned or that the pollutant should weigh about $80 \%$ of the total weight of the fabric to reach the age in which Jesus Christ lived in Palestine.

e. In fact, infinitesimal fractions of Carbon 14, perhaps produced by radiations acting on the nitrogen atoms present in the flax, would be enough, to vary the presumed age of millennia; furthermore it results that some substances are resistant to the cleaning methods then used by the laboratories in 1988 and therefore could have remained as contaminants in the tested samples. Many forget that the body image, still unexplainable, may have been produced by a burst of intense energy; why not think that just that burst of energy was responsible for the production of additional Carbon 14 as well as the body image?

\section{Is a Miracle out of a Scientific Discussion?}

If a burst of energy perhaps similar to that of a very powerful electric discharge would be necessary to get the yellowing of the fibers detected on the Shroud, a miracle should be supposed. This hypothesis obviously goes out of science and therefore the present discussion. Even if traditional science does not include the study of miracles, because these are not repeatable and reproducible phenomena at the experimenter's request, the same science must admit its powerlessness on the face of miracles certified by appropriate commissions of scientists or on front of the study of a complex body image like that of the Shroud. If science is impotent, all other conceivable alternatives, including miracles, cannot be excluded for the moment from a scientific analysis to explain something of this linen Sheet that we can touch and measure with the most modern scientific equipment, but that we cannot explain.

\section{References}

1. Adler AD (2014) The Orphaned Manuscript: A Gathering of Publications on the Shroud of Turin p. 21.

2. Antonacci M (2016) Test the Shroud: At the Atomic and Molecular Levels, Forefront Publishing Company; ( $1^{\text {st }}$ edn), USA.

3. Baraldi P, Tinti A (2015) Molecular Spectroscopy as an alternative for dating Textiles. MATEC, Web of Conferences, 36:01002.

4. Fanti G (2015) Introductory Paper: Scientific Results on the Turin Shroud Coming from a Paduan University Research Project, WOPSAS Conf., MATEC Web of Conferences, Vol. 36, https://www.matecconferences.org/articles/matecconf/abs/2015/17/contents/ contents.html

5. Heller JH (1980) AD. Adler - Blood on the Shroud of Turin - Applied Optics, 19(16): 2742-2744.

6. Jackson JP (2017) The Shroud of Turin: A Critical Summary of Observations, Data and Hypotheses.

7. Rogers R (2005) Studies on the radiocarbon sample from the shroud of turin. Thermochimica Acta 425: 189-194.

8. Schwalbe LA, Rogers RN (1982) Physics and chemistry of the Shroud of Turin, a summary of the 1978 investigation. Analytica Chimica Acta 135: 3-49.

9. Vignon p (1902) Le Linceul du Christ, Masson.

10. Wilson I, Miller V (1986) The Mysterious Shroud. Doubleday Image Book, USA.

11. Wilson I (1991) Holy Faces, Secret Places, Doubleday, London, UK.

12. Fanti G (2018) Why is the Turin Shroud Authentic? Glob J Arch \& Anthropol 7(2): 555707.

13. Garlaschelli L (2018) Perchè la sindone è un falso (Why the shroud is a fake). Scienza e Ricerca, Il Bo Live, Padua University, Italy.

14. Barcaccia G (2015) Uncovering the sources of DNA found on the Turin Shroud, Scientific Reports pp. 14484.

15. Bevilacqua M, Fanti G, D’Arienzo M, Porzionato A, Macchi V, et al. (2014) How was crucified the Man of the Turin Shroud? Injury 45: 142-148.

16. Bevilacqua M (2018) Rigor Mortis and News obtained by the Body's Scientific Reconstruction of the Turin Shroud Man.

17. Damon PE, Donahue DJ, Gore BH, Hatheway AL, Jull AJT, et al. (1989) Radiocarbon dating of the Shroud of Turin. Nature, 337: 611-615.

18. Faccini B et al. (2008) The death of the Shroud Man: an improved review. Int Conf on the Shroud, Columbus Ohio, USA.

19. Fanti G (2010) Microscopic and Macroscopic Characteristics of the Shroud of Turin Image Superficiality. J of Imaging Sci Technol 54(4): 040201-1/8.

20. Fanti G (2011) Hypotheses regarding the formation of the body image on the Turin Shroud. A critical compendium. J of Imaging Sci Technol 55(6): 060507.

21.Jackson JP, Jumper EJ, Ercoline WR (1982) Three-dimensional characteristic of the Shroud Image. IEEE Proceedings of the International Conference on Cybernetics and Society, pp. 559-575.

22. Moscardi G, (2008) Analysis by Raman Microscopy of Powder Samples Drawn from the Turin Shroud. Int Conf on the Shroud, Ohio State University, USA. 
23. Fanti G (2010) Can Corona Discharge explain the body image formation of the Turin Shroud? J Imaging Sci Technol 54(2): 020508.

24. Fanti G, Baraldi P, Basso R, Tinti A (2013) Non-destructive dating of ancient flax textiles by means of vibrational spectroscopy.67: 61-70.

25. Fanti G, Malfi P (2015) The Shroud of Turin - First century After Christ Pan Stanford Publishing Pte. Ltd, Singapore.

26. Fanti G, Malfi P, Crosilla F (2015) Mechanical and opto-chemical dating of Turin Shroud, MATEC, Web of Conferences, p. 36.

27. Fanti G, Zagotto G (2017) Blood reinforced by pigments in the reddish stains of the Turin Shroud. Journal of Cultural Heritage.

28. Laude JP, Fanti G (2017) Raman and Energy Dispersive Spectroscopy (EDS) Analyses of a Micro substance Adhering to a Fiber of the Turin Shroud. Applied Spectroscopy 71: 10.

29. Calliari IC, Canovaro (2011) Analysis of micro-particles vacuumed from the Turin Shroud, MATEC, Web of Conferences. J of Imaging Sci Technol 55(6): 060507.

30. Garello E (1984) The Shroud and the Popes, Corsi (Eds.), Turin.

31. Riani M (2012) Regression analysis with partially labeled regressors: carbon dating of the Shroud of Turin. Journal of Statistical Computing Stat Comput. 23(4) 551-561.
32. Garlaschelli L (2010) Life-size reproduction of the Shroud of Turin and its image. J Imaging Sci Technol 54 (4): 40301.

33. Fanti GT Heimburger (2011) Letter to the Editor: Comments on - LifeSize Reproduction of the Shroud of Turin and its Image. by Garlaschelli L (Eds.), J Imaging Sci Technol 55: 020102.

34. McCrone WC (2000) The Shroud Image. The Microscope 48, nํ2 p. 79 85.

35. Jumper EJ, Adler AD, Jackson JP, Pellicori SF, Heller JH, et al. (1984) A comprehensive examination of the various stains and images on the Shroud of Turin. Archaeological Chemistry III 22: 447-476.

36. Barbet PA (1963) Doctor at Calvary: the passion of our Lord Jesus Christ as described by a surgeon. The Earl of Wicklow (trans), Garden City, Image Books edn, New York, USA.

37. Fanti G, Lattarulo F, Pesavento G (2014) Experimental Results Using Corona Discharge to Attempt to Reproduce the Turin Shroud Image.

38. Jackson JP (1990) Is the image on the Shroud due to a process heretofore unknown to modern science? Shroud Spectrum International 34: 3-29.

39. Borrini M, Garlaschelli L (2018), A BPA Approach to the Shroud of Turin, J of Forensic Sciences, doi: 10.1111/1556-4029.13867

\section{Your next submission with Juniper Publishers} will reach you the below assets

- Quality Editorial service

- Swift Peer Review

- Reprints availability

- E-prints Service

- Manuscript Podcast for convenient understanding

- Global attainment for your research

- Manuscript accessibility in different formats

( Pdf, E-pub, Full Text, Audio)

- Unceasing customer service

Track the below URL for one-step submission https://juniperpublishers.com/online-submission.php 